\title{
Potential flood volume of Himalayan glacial lakes
}

\author{
K. Fujita ${ }^{1}$, A. Sakai ${ }^{1}$, S. Takenaka ${ }^{2}$, T. Nuimura ${ }^{1}$, A. B. Surazakov ${ }^{3}$, T. Sawagaki ${ }^{4}$, and T. Yamanokuchi ${ }^{5}$ \\ ${ }^{1}$ Graduate School of Environmental Studies, Nagoya University, Nagoya, Japan \\ ${ }^{2}$ Earth System Science, Co. Ltd., Tokyo, Japan \\ ${ }^{3}$ College of Science, University of Idaho, Moscow, Idaho, USA \\ ${ }^{4}$ Graduate School of Environmental Science, Hokkaido University, Sapporo, Japan \\ ${ }^{5}$ Remote Sensing Technology Centre of Japan, Tsukuba, Japan \\ Correspondence to: K. Fujita (cozy@nagoya-u.jp)
}

Received: 2 January 2013 - Published in Nat. Hazards Earth Syst. Sci. Discuss.: 29 January 2013

Revised: 15 May 2013 - Accepted: 15 June 2013 - Published: 16 July 2013

\begin{abstract}
Glacial lakes are potentially dangerous sources of glacial lake outburst floods (GLOFs), and represent a serious natural hazard in Himalayan countries. Despite the development of various indices aimed at determining the outburst probability, an objective evaluation of the thousands of Himalayan glacial lakes has yet to be completed. In this study we propose a single index, based on the depression angle from the lakeshore, which allows the lakes to be assessed using remotely sensed digital elevation models (DEMs). We test our approach on five lakes in Nepal, Bhutan, and Tibet using images taken by the declassified Hexagon KH-9 satellite before these lakes experienced an outburst flood. All five lakes had a steep lakefront area (SLA), on which a depression angle was steeper than our proposed threshold of $10^{\circ}$ before the GLOF event, but the SLA was no longer evident after the events. We further calculated the potential flood volume (PFV); i.e., the maximum volume of floodwater that could be released if the lake surface was lowered sufficiently to eradicate the SLA. This approach guarantees repeatability to assess the possibility of GLOF hazards because it requires no particular expertise to carry out, though the PFV does not quantify the GLOF risk. We calculated PFVs for more than 2000 Himalayan glacial lakes using visible band images and DEMs of ASTER data. The PFV distribution follows a power-law function. We found that 794 lakes did not have an SLA, and consequently had a PFV of zero, while we also identified 49 lakes with PFVs of over 10 million $\mathrm{m}^{3}$, which is a comparable volume to that of recorded major GLOFs. This PFV approach allows us to preliminarily identify and prioritize those Himalayan glacial lakes that require further detailed investigation on GLOF hazards and risk.
\end{abstract}

\section{Introduction}

Glacial lake outburst floods (GLOFs) represent a serious natural hazard in Himalayan countries (e.g., Vuichard and Zimmermann, 1987; Yamada, 1998; Dwivedi et al., 2000; Richardson and Reynolds, 2000; Mool et al., 2001a, b). Consequently, assessing the likely risk of a GLOF from individual glacial lakes is important when allocating limited human and financial resources to potential countermeasures. Although detailed in situ surveys have been able to quantify the potential of outburst flooding from individual glacial lakes (Reynolds, 1999; Iwata et al., 2002; Fujita et al., 2008), it is impractical to perform such ground-based investigations on the thousands of Himalayan glacial lakes. A remote sensing approach offers a possible solution to this problem in the Himalayas, where ground-based measurements are hampered by the high altitude and remoteness (Bolch et al., 2008; Wang et al., 2008; Wang et al., 2011). In particular, 44 glacial lakes in Bhutan and Nepal have been identified as potentially dangerous glacial lakes (Mool et al., 2001a, b) though no criterion has been given. Although many indices have been proposed by previous studies (Clague and Evans, 2000; Richardson and Reynolds, 2000; McKillop and Clague, 2007a, b; Bolch et al., 2008, 2011; Wang et al., 2008; Mergili and Schneider, 2011; X. Wang et al., 2012), uncertainties remain with respect to the choice of the most effective criteria with which to objectively evaluate GLOF probability. In addition to those studies evaluating GLOF probability, risk assessment is also an important social request for the GLOF-relevant research. In this regard, some studies have conducted flood simulations and then assessed the 
flood-affected areas downstream (Bajracharya et al., 2007; Koike and Takenaka, 2012; W. Wang et al., 2012). Although flood water volume is an essential parameter as an initial condition of such flood simulations, it is unclear how much water will be released in case of GLOF. Peak discharge, which was empirically estimated from lake volume, has been conventionally used in some cases (e.g. Huggel et al., 2002; McKillop and Clague, 2007a).

Most previous studies assessing GLOF probability have focused on the expansion rates of glacial lakes, and the steep terrain surrounding the lakes from which an ice/rock mass could fall into the lake (Richardson and Reynolds, 2000; Bolch et al., 2008; Wang et al., 2008), while only a few studies have examined the stability of the damming moraine as this requires the collection of in situ data (Clague and Evans, 2000; Hambrey et al., 2008; Fujita et al., 2009; Ohashi et al., 2012). As glacial lakes are situated in remote mountainous areas, the actual trigger for GLOF events has rarely been witnessed (Dwivedi et al., 2000). On the other hand, a V-shaped trench cutting the damming moraine and a debris fan in front of the lake provided evidences of dam breaches caused by GLOFs (Komori et al., 2012). Consequently, in this study we assume that failure of the damming moraine is essential to release an effective amount of lake water, which may cause damage downstream, regardless of the trigger mechanism. Using recent evidence of a link between the topography of lakes and the surrounding areas (Clague and Evans, 2000; McKillop and Clague, 2007a, b; Fujita et al., 2008, 2009; Komori et al., 2012), we propose a new, single index to objectively quantify the potential hazard from glacial lakes that is based on a simple remote sensing approach, and attempt to prioritize thousands of Himalayan glacial lakes by evaluating possible flood volume in case of GLOF.

\section{Methods and data}

\subsection{Methods}

To evaluate the likely hazard of GLOF, we developed an index based on the depression angle between the flat lake surface and the surrounding terrain (Fig. 1) using remotely sensed DEMs. Although the depression angle is simply an alternative measurement of the width-to-height ratio of the damming moraine (Clague and Evans, 2000; Huggel et al., 2002; McKillop and Clague, 2007a, b), this angle can be easily calculated from DEMs, whereas it is often difficult to identify moraine boundaries from satellite imagery and thus the width-to-height ratio itself may have a large uncertainty associated with it. We examined the terrain within $1 \mathrm{~km}$ of the targeted lakes and calculated the elevation angle from a given point towards the lake surface (i.e., the depression angle from the lake); the steepest angle measured (i.e., to the nearest section of lakeshore) was taken as the value for that point.

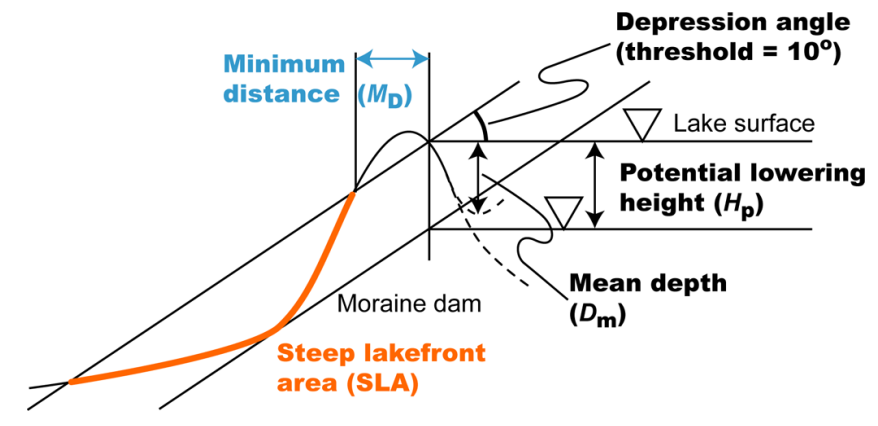

Fig. 1. The concept of the steep lakefront area (SLA), potential lowering height $\left(H_{\mathrm{p}}\right)$, mean depth $\left(D_{\mathrm{m}}\right)$, and minimum distance $\left(M_{\mathrm{D}}\right)$ for a glacial lake. The threshold angle $\left(10^{\circ}\right)$ used to define the SLA was obtained by evaluating pre-GLOF topography in Hexagon KH9 images (Fig. 5).

Having determined the threshold angle $\left(10^{\circ}\right.$ as described later), we can define the steep lakefront area (SLA) in front of the glacial lake (Fig. 1). As the glacial lakes have no SLA after the GLOF events, we excluded lakes without an SLA from the following analysis. We assumed a potential lowering height $\left(H_{\mathrm{p}}\right)$ that would lead to the removal of the SLA if the lake surface was lowered without any change in the shoreline following outburst (Fig. 1). Some small glacial lakes have a very deep $H_{\mathrm{p}}$ if they are situated above a very large and steep slope. However, it is implausible that such small lakes $\left(0.01 \mathrm{~km}^{2}\right.$, for instance) are deeper than $100 \mathrm{~m}$, which is equivalent to the maximum depth of some typical Himalayan glacial lakes, which may be up to $1 \mathrm{~km}^{2}$ in area (Yamada, 1998; Fujita et al., 2009). We therefore constrained the depth of the glacial lakes based on an areadepth relationship obtained from several Himalayan glacial lakes (Vuichard and Zimmermann, 1987; Liu and Sharma, 1988; Yamada, 1998; Benn et al., 2000; Dwivedi et al., 2000; Yamada et al., 2004; Fujita et al., 2009; ICIMOD, 2011; Sakai, 2012) (Fig. 2):

$D_{\mathrm{m}}=55 A^{0.25}$

where $A$ and $D_{\mathrm{m}}$ are the lake area $\left(\mathrm{km}^{2}\right)$ and mean depth of the lake $(\mathrm{m})$, respectively. This is the maximum approximation as shown in Fig. 2. Here, we use the mean depth, rather than the maximum depth, to estimate flood volume because the GLOF events did not result in the complete drainage of the lake. Finally, we obtained the potential flood volume (PFV) from

$\mathrm{PFV}=\min \left[H_{\mathrm{p}} ; D_{\mathrm{m}}\right] A$.

We used whichever of the potential lowering height $\left(H_{\mathrm{p}}\right)$ or the mean depth $\left(D_{\mathrm{m}}\right)$ had the smaller value for the lowering height in the event of outburst, and assumed a cylindrical bathymetry (i.e., no change in lakeshore following a lowering in lake level) to calculate the maximum flood volume, because lake bathymetry cannot be obtained using remote sensing techniques. 


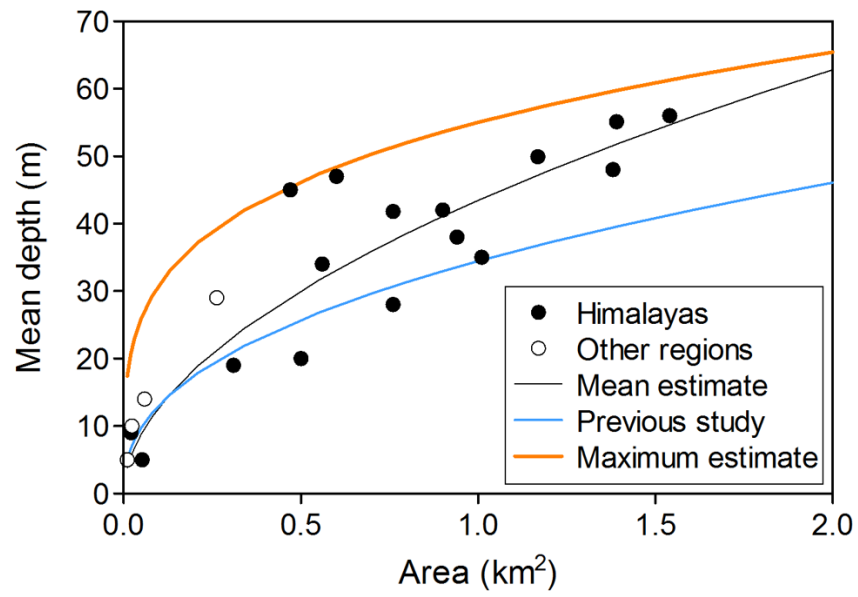

Fig. 2. Observational relationship between lake area and mean depth of Himalayan glacial lakes (solid dots). Open dots are moraine-dammed lakes in other regions of the world (Clague and Evans, 2000; Huggel et al., 2002). Thin black, blue, and orange lines show an approximate curvilinear fit for the observational data, and for other glacial lakes worldwide (Huggel et al., 2002), and the maximum approximate curve used to constrain lake depth in this study, respectively.

\subsection{Validation using Hexagon KH-9 data}

As we assume that the collapse of the damming moraine releases a significant amount of lake water, a typical Himalayan glacial lake, with its steep and narrow moraine-dam, must have a relatively high outburst potential (Costa and Schuster, 1988). We therefore expect that the probability of a GLOF event is related to some threshold value of the depression angle; but how steep is this threshold? To determine the threshold angle, we used declassified Hexagon KH-9 satellite imagery obtained between 1973 and 1980 from five glacial lakes in Nepal, Bhutan, and Tibet, for which pre-GLOF images were available (Table 1). We generated Hexagon KH9 DEMs with a resolution of $10 \mathrm{~m}$ from stereo pair images. First, image distortion, which was introduced by the development and double duplication of the film, and almost three decades of storage, was corrected by the method proposed by Surazakov and Aizen (2010). Second, a detailed terrain editing procedure was performed on the triangulated irregular network (TIN) using the Leica Terrain Format software to further correct and reduce errors related to the irregular microtopography, high relief, and shadows on the images (Lamsal et al., 2011; Sawagaki et al., 2012). The lake boundaries were identified during the TIN-editing procedure and several ground control points were identified from the Google Earth images around each target lake. The accuracy of this procedure around glacial lakes in the Nepal Himalaya was evaluated to be $\pm 5 \mathrm{~m}$ by comparing DEMs generated from the Corona images, which are similarly declassified satellite data, and the ALOS (Advanced Land Observing
Satellite) stereo images, which are up-to-date high-resolution satellite data (Lamsal et al., 2011; Sawagaki et al., 2012). We assumed that the accuracy of the Hexagon DEMs was equivalent to that of the Corona DEMs. Using the Hexagon KH-9 DEMs, we finally obtained the depression angle, and from this the SLA, around the five training glacial lakes prior to the GLOF events.

\subsection{ASTER data}

As absolute consistency is required between the visible image and the digital elevation model (DEM), we used a Level 3A01 product from the ASTER-orthorectified images, including a relative DEM (spatial resolution of $15 \mathrm{~m}$ ) for the present-day analysis. This is a semi-standard orthorectified image generated from the Level-1A data by the ASTER Ground Data System (ASTER GDS) at the Earth Remote Sensing Data Analysis Centre (ERSDAC) in Japan. The relative DEM was produced with data from two telescopes, one a nadir-looking visible/near-infrared (VNIR) (band 3N) and the other a backward-looking VNIR (band 3B) without ground control point correction for individual scenes (Fujisada et al., 2005). Accuracy of the ASTER-DEMs in the Bhutan and Nepal Himalayas was evaluated to be $12.9 \pm 1.9 \mathrm{~m}$ by precise GPS measurements, and it depends on image quality (cloud and/or snow cover) (Fujita et al., 2008; Nuimura et al., 2012).

We delineated 4037 glacial lakes across the Himalayas on 140 scenes of ASTER data (Table S1). Lake boundaries were manually delineated by referring to the normalized differentiated water index with visual checking and editing to rectify errors due to ice areas and shadows on the lake (Huggel et al., 2002; Bolch et al., 2008; Fujita et al., 2009). We confined our targets to moraine-dammed lakes situated within the latest moraine formed during the Little Ice Age, and excluded supraglacial ponds, and lakes dammed by glaciers (Fig. 3), because their drainage-induced flood mechanism may be different to floods caused by moraine-dam collapse (Komori et al., 2012; Fujita et al., 2012). From the 4037 glacial lakes, we checked and excluded redundantly delineated lakes, and selected 2276 lakes (Table S1) with the most accurate surface elevation data (smaller standard deviation of lake elevation). Of the 2276 Himalayan glacial lakes, 931 were examined several times using data taken on different dates. We found 24 lakes having a standard deviation greater than $13 \mathrm{~m}$, while the measured surface elevation of $94.4 \%$ of the glacial lakes had standard errors of less than $1 \mathrm{~m}$ (Fig. 4).

\subsection{Error evaluation}

Both the depth estimation and area delineation may cause uncertainty in the PFV estimates. We evaluated the PFV uncertainty (dPFV) as

$\mathrm{dPFV}=A d_{D}+d_{A} D$. 
Table 1. Characteristics of the five GLOF lakes studied (Fig. 5).

\begin{tabular}{|c|c|c|c|c|c|c|c|c|c|c|c|c|c|}
\hline Lake & $\begin{array}{r}\text { Area } \\
\left(\mathrm{km}^{2}\right)\end{array}$ & $\begin{array}{r}\mathrm{LON} \\
\left({ }^{\circ}\right)\end{array}$ & $\begin{array}{r}\text { LAT } \\
\left({ }^{\circ}\right)\end{array}$ & $\begin{array}{r}Z \\
\text { (ma.s.l.) }\end{array}$ & $\begin{array}{r}\text { SLA } \\
\left(\mathrm{km}^{2}\right)\end{array}$ & $\begin{array}{l}M_{\mathrm{D}} \\
(\mathrm{m})\end{array}$ & $\begin{array}{r}H_{\mathrm{p}} \\
(\mathrm{m})\end{array}$ & $\begin{array}{l}D_{\mathrm{m}} \\
(\mathrm{m})\end{array}$ & $\begin{array}{r}\mathrm{PFV} \\
\left(\text { million } \mathrm{m}^{3}\right)\end{array}$ & $\begin{array}{r}\mathrm{FV} \\
\left(\text { million } \mathrm{m}^{3} \text { ) }\right.\end{array}$ & $\begin{array}{l}\text { Hexagon } \\
\text { acquisition date }\end{array}$ & $\begin{array}{l}\text { ASTER } \\
\text { acquisition date }\end{array}$ & $\begin{array}{l}\text { Date of } \\
\text { outburst }\end{array}$ \\
\hline Nagma & 0.66 & 87.867 & 27.870 & 4858 & 0.244 & 28 & 60 & 50 & 32.8 & N/A & 20 Dec 1975 & 19 Nov 2007 & 23 Jun 1980 \\
\hline Dig & 0.34 & 86.584 & 27.875 & 4336 & 0.050 & 255 & 21 & 42 & 7.1 & 5.0 & 21 Nov. 1973 & 23 Jan 2006 & 4 Aug 1985 \\
\hline Lugge & 1.14 & 90.296 & 28.094 & 4544 & 0.029 & 14 & 13 & 57 & 14.9 & 17.2 & 24 Nov 1974 & 1 Jan 2008 & 7 Oct 1994 \\
\hline Sabai/Tam & 0.38 & 86.845 & 27.743 & 5227 & 0.357 & 193 & 52 & 43 & 16.3 & 17.7 & 14 Dec 1973 & 23 Jan 2006 & 3 Sep 1998 \\
\hline Unnamed & 0.46 & 89.745 & 28.211 & 4812 & 0.066 & 168 & 16 & 45 & 7.2 & N/A & 5 Nov 1974 & 9 Dec 2002 & unknown \\
\hline
\end{tabular}

Abbreviations denote longitude $(\mathrm{LON})$, latitude $(\mathrm{LAT})$, altitude $(Z)$, steep lakefront area (SLA), minimum distance between lakeshore and SLA $\left(M_{\mathrm{D}}\right)$, potential lowering height $\left(H_{\mathrm{p}}\right)$, mean depth estimated from lake area $\left(D_{\mathrm{m}}\right)$, potential flood volume (PFV), and flood volume (FV). Flood volumes are based on previous studies (Vuichard and Zimmermann, 1987; Dwivedi et al., 2000; Fujita et al., 2008). Lake area of Lugge Tsho is based on a SPOT image taken one year before the GLOF event (Fujita et al., 2008).
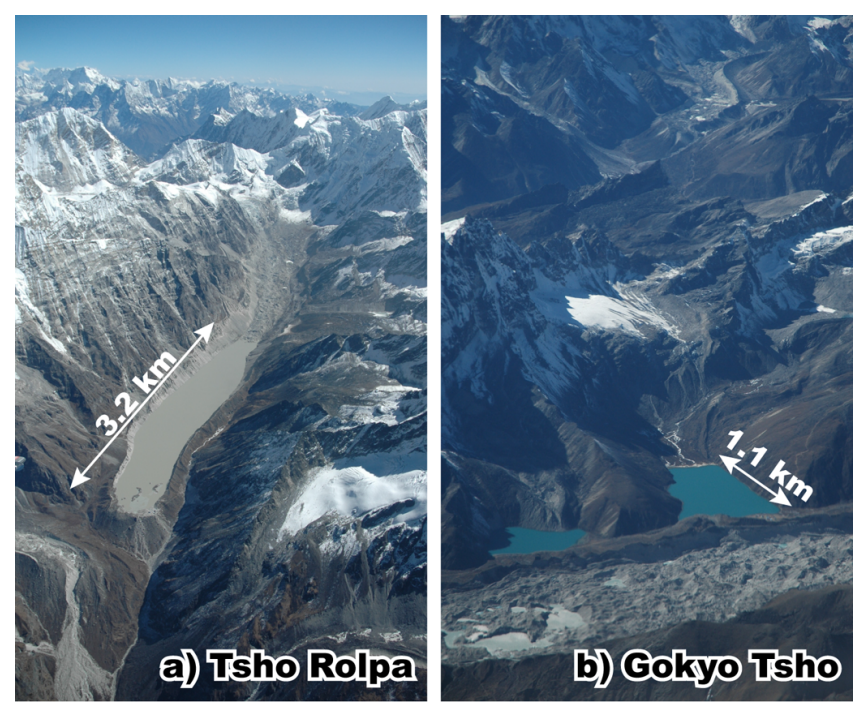

Fig. 3. (a) Moraine-dammed lake examined in this study (Tsho Rolpa having the greatest potential flood volume) and (b) glacierdammed lake excluded from the analysis (Gokyo Tsho). Both lakes are in Nepal. Photos taken in November 2007.

Here, $d_{D}$ and $d_{A}$ are errors of depth estimation and area delineation, respectively. $D$ is whichever of the potential lowering height $\left(H_{\mathrm{p}}\right)$ or the mean depth $\left(D_{\mathrm{m}}\right)$ had the smaller value $\left(\min \left[H_{\mathrm{p}} ; D_{\mathrm{m}}\right]\right)$. The depth estimated using Eq. (1) may lead to a high degree of uncertainty in the estimated PFV. To evaluate the depth uncertainty $\left(d_{D}\right)$, we calculated the root mean square error for the approximated curve as $7.03 \mathrm{~m}$ using the relationship between the area and mean depth of Himalayan glacial lakes (black line in Fig. 2). The delineation error of the lake boundary may also cause uncertainty in the PFV estimates. We therefore estimated the area uncertainty $\left(d_{A}\right)$ by multiplying the shoreline length by $7.5 \mathrm{~m}$, which is half of the cell resolution of the ASTER VNIR data (Fujita et al., 2009).

\section{Results}

Pre-GLOF images obtained from the Hexagon KH-9 satellite show that all five lakes had an SLA to their damming

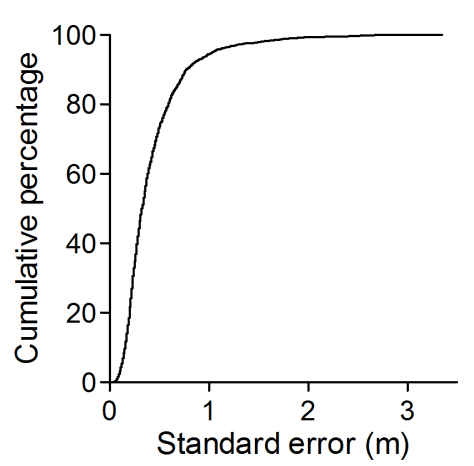

Fig. 4. Cumulative frequency distributions for the 2276 Himalayan glacial lakes against standard error of lake surface elevation.

moraine, but no SLA was observed in front of the lakes after the outburst flood if a threshold of $10^{\circ}$ is assumed for the depression angle (Table 1; Fig. 5). Cross-sections along the outlet clearly show the significant changes in steepness along the flow channels following the GLOF events (Fig. 6). It should be noted that the pre-GLOF (thick coloured line) and the post-GLOF (dashed line in the same colour) crosssections do not represent the same streamline, and that the post-GLOF cross-sections from the ASTER-DEMs show irregular bumps due to uncertainty within the DEMs. This suggests that the collapse of the damming moraine may have ceased when the slope of the flood channel became less than $10^{\circ}$ when it then, once again, acted as a robust dam. This also suggests that a glacial lake with no SLA would be unlikely to suffer a GLOF. A previous dam breach simulation also suggested that a gently sloping moraine $\left(<10^{\circ}\right)$ could not initiate a breach, even under a large water inflow (Koike and Takenaka, 2012). Among the five training lakes, the PFVs and actual flood volumes estimated by alternative methods (hydrograph or in situ survey) for the three GLOF lakes (Dig, Sabai, and Lugge) were fairly similar (Table 1).

We applied the criteria to 2276 glacial lakes across the Himalayas whose area is larger than $0.005 \mathrm{~km}^{2}$ (Fig. 7). We found that 794 lakes did not have an SLA, and consequently had a PFV of zero. In particular, 23 out of 44 lakes, which were originally classified by Mool et al. (2001a, b) as potentially dangerous, were deemed safe because no SLA was 


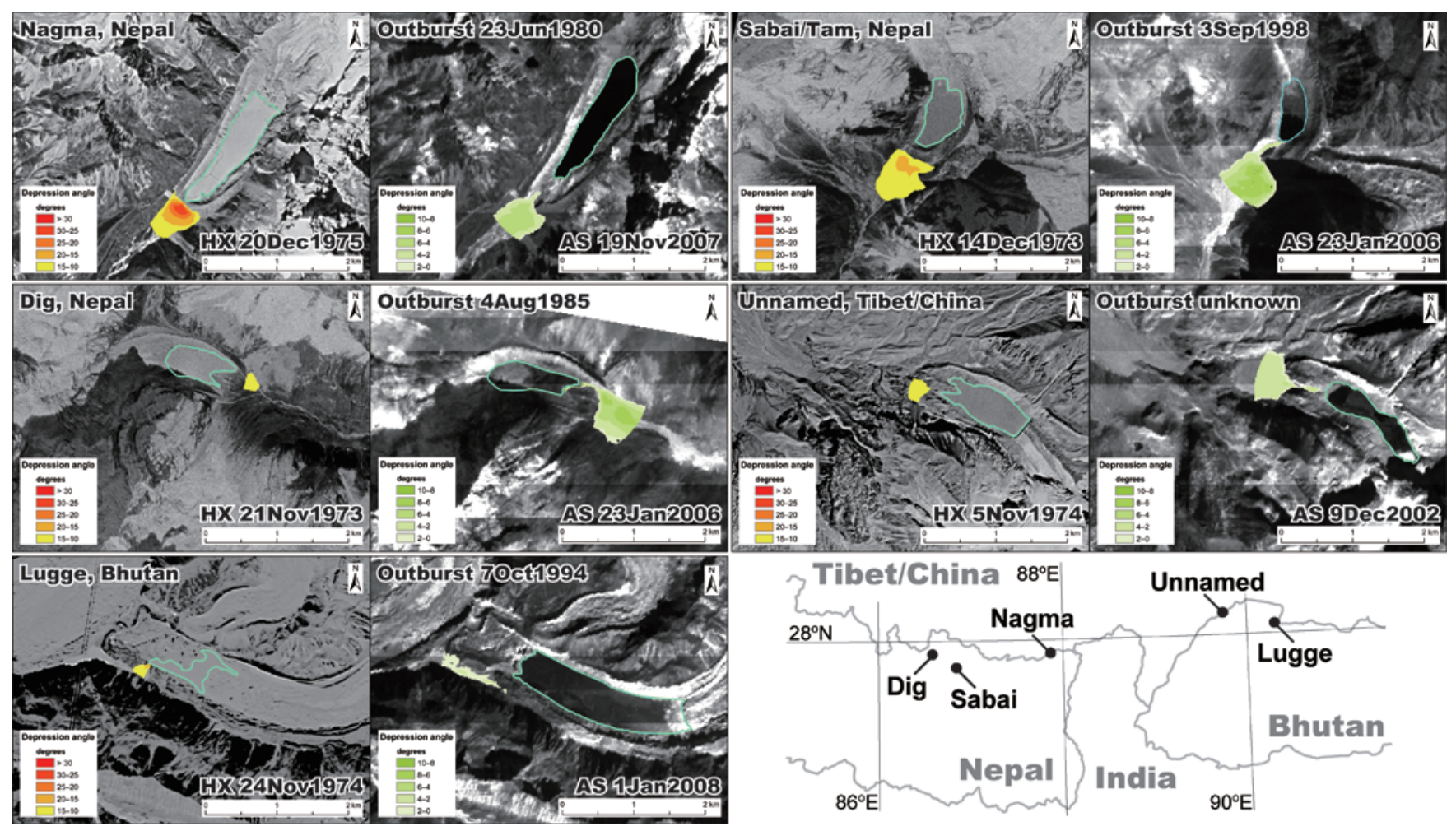

Fig. 5. Pre- (HX) and post-GLOF (AS) images of the five lakes showing changes in depression angle (details in Table 1). Acquisition dates area indicated after HX (Hexagon) and AS (ASTER).

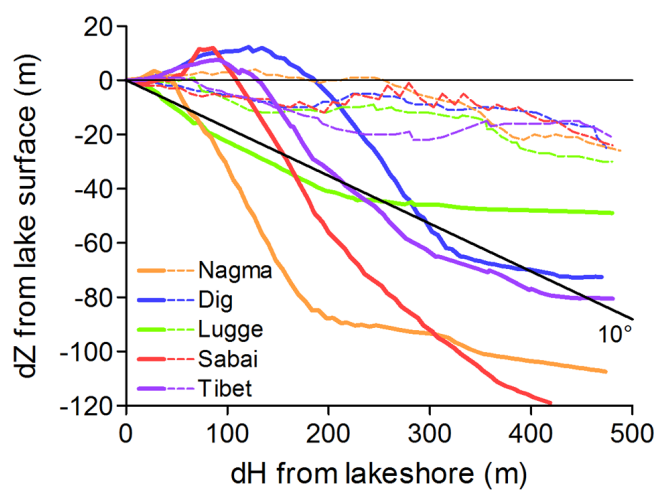

Fig. 6. Pre-GLOF (thick lines) and post-GLOF (thin dashed lines) cross-sections along the outlet of five training glacial lakes in the Himalayas (Fig. 5; Table 1). Horizontal and vertical axes denote horizontal distance from the lakeshore $(\mathrm{dH})$ and relative elevation from the lake surface $(\mathrm{dZ})$, respectively. Also shown is a black line along the threshold angle of $10^{\circ}$. Lake "Tibet" denotes the unnamed lake in Tibet. Note that the lakeshores $(\mathrm{dH}=\mathrm{dZ}=0)$ are not at the same location in the pre- and post-GLOF images.

found on these lakes (Table 2). The remaining 21 lakes still show some degree of PFV (10 lakes in Nepal and 11 in Bhutan; Table 2). We list 49 lakes having a PFV greater than 10 million $\mathrm{m}^{3}$ (Table 3), which is a comparable volume to that of recorded major GLOFs. Figure 8 shows 18 lakes having PFVs greater than 20 million $\mathrm{m}^{3}$. Major glacial lakes with a large PFV value appear to be located around the eastern Nepal to Bhutan Himalayas (Fig. 7), where glacial lakes show rather rapid expansion rates (Gardelle et al., 2011). This implies that the PFV will increase over time associated with expansion of the lake area.

Figure 9 a shows the level of uncertainty associated with the estimated PFVs, and the linear regression line suggests that the PFVs have an uncertainty of about $26 \%$, which is mainly caused by the uncertainty of depth estimation ( $21 \%$; Fig. 9b) rather than that of area delineation (5.0\%; Fig. 9c). We examined how the potential flood volume of Himalayan glacial lakes responds to the threshold angle (Fig. 10; Table 4). Steep lakefront area (SLA) and associated potential flood volume (PFV) appeared (or disappeared) when the threshold angle decreased (or increased). We found no pattern for the threshold by which a large SLA and PFV appeared on which lake, because the SLA depends on the location relative to the lakeshore and surrounding moraine, and the PFV depends on lowering of the lake level (relative to the SLA) and lake area. In any threshold angles, the cumulative frequency distributions follow a power-law function (Fig. 10). 
Table 2. Potential flood volume (PFV) of potentially dangerous glacial lakes identified by previous studies (Mool et al., 2001a, b).

\begin{tabular}{|c|c|c|c|c|c|}
\hline ID* & Lake & $\begin{array}{l}\text { PFV } \\
\left(\text { million } \mathrm{m}^{3}\right)\end{array}$ & $\begin{array}{l}\text { Longitude } \\
\left({ }^{\circ}\right)\end{array}$ & $\begin{array}{l}\text { Latitude } \\
\left({ }^{\circ}\right)\end{array}$ & Country \\
\hline Gka_gl 38 & unnamed & 0 & 83.674 & 29.046 & Nepal \\
\hline Gka_gl 67 & unnamed & 0 & 83.684 & 29.201 & Nepal \\
\hline Gmar_gl 70 & Thulagi & 0.6 & 84.485 & 28.488 & Nepal \\
\hline Gbu_gl 9 & unnamed & 0 & 84.630 & 28.597 & Nepal \\
\hline Kta_gl 26 & Rolpa & 89.6 & 86.477 & 27.861 & Nepal \\
\hline Kdh_gl 28 & Lumding & 5.2 & 86.615 & 27.779 & Nepal \\
\hline Kdh_gl 55 & Dig & 0 & 86.584 & 27.875 & Nepal \\
\hline Kdh_gl 350 & Imja & 0 & 86.923 & 27.899 & Nepal \\
\hline Kdh_gl 399 & Tam/Sabai & 0.4 & 86.845 & 27.743 & Nepal \\
\hline Kdh_gl 422 & Dudh & 12.1 & 86.859 & 27.688 & Nepal \\
\hline Kdh_gl 442 & unnamed & 6.4 & 86.911 & 27.794 & Nepal \\
\hline Kdh_gl 444 & unnamed & not glacial lake & 86.943 & 27.797 & Nepal \\
\hline Kdh_gl 449 & Hunku & 0 & 86.935 & 27.837 & Nepal \\
\hline Kdh_gl 459 & East Hungu 1 & 0 & 86.966 & 27.799 & Nepal \\
\hline Kdh_gl 462 & East Hungu 2 & 2.6 & 86.974 & 27.805 & Nepal \\
\hline Kdh_gl 464 & unnamed & 32.1 & 86.957 & 27.783 & Nepal \\
\hline Kdh_gl 466 & West Chamjang & 4.8 & 86.956 & 27.754 & Nepal \\
\hline N/A & Lower Barun & 0 & 87.096 & 27.797 & Nepal \\
\hline Ktr_gl 146 & unnamed & 5.6 & 87.749 & 27.815 & Nepal \\
\hline Ktr_gl 192 & Nagma & 0 & 87.867 & 27.870 & Nepal \\
\hline Mo_gl 200 & $\mathrm{Kab}$ & 1.3 & 89.580 & 28.069 & Bhutan \\
\hline Mo_gl 201 & unnamed & 1.6 & 89.602 & 28.115 & Bhutan \\
\hline Mo_gl 202 & unnamed & 0.8 & 89.611 & 28.125 & Bhutan \\
\hline Mo_gl 234 & Setang Burgi & 8.9 & 89.848 & 28.172 & Bhutan \\
\hline Mo_gl 235 & unnamed & 5.2 & 89.841 & 28.144 & Bhutan \\
\hline Pho_gl 84 & unnamed & 0 & 89.931 & 27.942 & Bhutan \\
\hline Pho_gl 148 & unnamed & 33.7 & 89.931 & 27.973 & Bhutan \\
\hline Pho_gl 163 & unnamed & 0 & 89.899 & 28.105 & Bhutan \\
\hline Pho_gl 164 & Tarina & 2.7 & 89.910 & 28.113 & Bhutan \\
\hline Pho_gl 209 & Raphstreng & 0 & 90.246 & 28.105 & Bhutan \\
\hline Pho_gl 210 & Lugge & 0 & 90.296 & 28.094 & Bhutan \\
\hline Pho_gl 211 & unnamed & 2.6 & 90.326 & 28.087 & Bhutan \\
\hline Pho_gl 313 & unnamed & 0 & 90.130 & 27.988 & Bhutan \\
\hline Mang_gl 99 & unnamed & 0 & 90.276 & 27.907 & Bhutan \\
\hline Mang_gl 106 & Metatshota & 0 & 90.290 & 27.891 & Bhutan \\
\hline Mang_gl 270 & unnamed & 8.3 & 90.332 & 27.970 & Bhutan \\
\hline Mang_gl 285 & unnamed & 0 & 90.328 & 28.006 & Bhutan \\
\hline Mang_gl 307 & unnamed & 0 & 90.364 & 28.039 & Bhutan \\
\hline Mang_gl 310 & unnamed & 0 & 90.382 & 27.981 & Bhutan \\
\hline Mang_gl 385 & unnamed & 0 & 90.438 & 27.985 & Bhutan \\
\hline Cham_gl 198 & unnamed & 27.7 & 90.535 & 27.941 & Bhutan \\
\hline Cham_gl 232 & unnamed & 2.5 & 90.508 & 27.973 & Bhutan \\
\hline Cham_gl 383 & Chubda & 0 & 90.709 & 28.024 & Bhutan \\
\hline Kuri_gl 172 & unnamed & not glacial lake & 91.300 & 27.930 & Bhutan \\
\hline
\end{tabular}

* IDs are given by International Centre for Integrated Mountain Development (Mool et al., 2001a,b).

\section{Discussion}

The calculated PFV represents a maximum projection because we assume a cylindrical bathymetry, and this implies no change in the shoreline following lowering of the lake surface by the flooding, while the bathymetry of real glacial lakes gradually deepens from the downstream to the upstream side (Yamada, 1998; Fujita et al., 2009). Considering such a shallow bathymetry, the lowering of the lake surface by outburst flooding would result in the retreat of the lakeshore upstream, causing the SLA to be removed more quickly than would be the case for the assumed cylindrical 
Table 3. Glacial lakes with high potential flood volume. Abbreviations are shown in the footnote of Table 1.

\begin{tabular}{|c|c|c|c|c|c|c|c|c|c|c|}
\hline Rank & $\begin{array}{r}\text { PFV } \\
\left(\text { million } \mathrm{m}^{3}\right)\end{array}$ & $\begin{array}{r}\text { Area } \\
\left(\mathrm{km}^{2}\right)\end{array}$ & $\begin{array}{r}\text { LON } \\
\left({ }^{\circ}\right)\end{array}$ & $\begin{array}{r}\text { LAT } \\
\left({ }^{\circ}\right)\end{array}$ & $\begin{array}{r}Z \\
\text { (m a.s.l.) }\end{array}$ & $\begin{array}{r}\text { SLA } \\
\left(\mathrm{km}^{2}\right)\end{array}$ & $\begin{array}{l}M_{\mathrm{D}} \\
(\mathrm{m})\end{array}$ & $\begin{array}{l}H_{\mathrm{p}} \\
(\mathrm{m})\end{array}$ & $\begin{array}{l}D_{\mathrm{m}} \\
(\mathrm{m})\end{array}$ & $\begin{array}{r}\text { Year of } \\
\text { image }\end{array}$ \\
\hline 1 & 89.6 & 1.477 & 86.477 & 27.862 & 4496 & 0.449 & 15 & 107 & 61 & 2007 \\
\hline 2 & 48.4 & 0.903 & 94.965 & 29.546 & 4232 & 0.291 & 181 & 86 & 54 & 2007 \\
\hline 3 & 42.1 & 3.619 & 85.841 & 28.319 & 5049 & 0.068 & 15 & 12 & 76 & 2005 \\
\hline 4 & 36.8 & 0.853 & 87.771 & 27.927 & 4884 & 0.228 & 15 & 43 & 53 & 2001 \\
\hline 5 & 34.0 & 0.681 & 91.553 & 27.834 & 4472 & 0.312 & 593 & 172 & 50 & 2007 \\
\hline 6 & 33.7 & 0.676 & 89.931 & 27.973 & 5035 & 0.568 & 255 & 162 & 50 & 2006 \\
\hline 7 & 32.1 & 0.650 & 86.957 & 27.783 & 5162 & 0.858 & 394 & 147 & 49 & 2005 \\
\hline 8 & 31.5 & 0.788 & 87.592 & 28.23 & 5373 & 0.236 & 631 & 40 & 52 & 2007 \\
\hline 9 & 31.2 & 0.635 & 81.78 & 30.128 & 4988 & 1.275 & 15 & 202 & 49 & 2000 \\
\hline 10 & 30.8 & 1.135 & 85.51 & 28.624 & 5077 & 0.479 & 15 & 27 & 57 & 2008 \\
\hline 11 & 30.5 & 0.756 & 90.268 & 28.106 & 4415 & 0.154 & 188 & 40 & 51 & 2001 \\
\hline 12 & 27.7 & 0.578 & 90.536 & 27.94 & 4986 & 0.419 & 318 & 178 & 48 & 2008 \\
\hline 13 & 25.5 & 0.540 & 86.515 & 28.045 & 5194 & 0.692 & 150 & 83 & 47 & 2008 \\
\hline 14 & 24.3 & 5.236 & 85.61 & 28.533 & 5316 & 0.016 & 242 & 5 & 83 & 2003 \\
\hline 15 & 22.3 & 0.486 & 88.288 & 28.018 & 5215 & 0.193 & 106 & 64 & 46 & 2007 \\
\hline 16 & 22.3 & 0.485 & 87.641 & 28.094 & 5131 & 0.231 & 108 & 53 & 46 & 2007 \\
\hline 17 & 22.0 & 0.480 & 90.223 & 28.929 & 5054 & 0.370 & 15 & 84 & 46 & 2008 \\
\hline 18 & 21.2 & 0.670 & 88.546 & 27.993 & 5139 & 0.228 & 329 & 32 & 50 & 2001 \\
\hline 19 & 19.4 & 0.434 & 86.929 & 27.85 & 5350 & 0.701 & 45 & 121 & 45 & 2008 \\
\hline 20 & 18.8 & 0.424 & 90.996 & 27.896 & 4334 & 0.800 & 192 & 282 & 44 & 2007 \\
\hline 21 & 18.6 & 0.419 & 89.227 & 27.809 & 5106 & 0.595 & 162 & 114 & 44 & 2005 \\
\hline 22 & 18.4 & 0.417 & 80.785 & 30.401 & 5062 & 0.208 & 363 & 120 & 44 & 2006 \\
\hline 23 & 17.6 & 0.402 & 91.269 & 27.932 & 4689 & 0.673 & 15 & 241 & 44 & 2007 \\
\hline 24 & 16.8 & 1.052 & 88.714 & 28.007 & 5206 & 0.100 & 201 & 16 & 56 & 2000 \\
\hline 25 & 16.1 & 0.375 & 82.415 & 29.754 & 4632 & 0.199 & 391 & 152 & 43 & 2009 \\
\hline 26 & 16.1 & 0.375 & 91.597 & 28.027 & 4764 & 0.266 & 30 & 61 & 43 & 2007 \\
\hline 27 & 15.8 & 0.771 & 87.931 & 27.951 & 5054 & 0.067 & 477 & 20 & 52 & 2007 \\
\hline 28 & 15.8 & 0.368 & 94.891 & 29.375 & 4395 & 0.857 & 150 & 264 & 43 & 2007 \\
\hline 29 & 15.7 & 0.366 & 90.952 & 28.05 & 4593 & 0.444 & 300 & 115 & 43 & 2005 \\
\hline 30 & 14.4 & 0.342 & 86.621 & 27.79 & 5108 & 1.477 & 15 & 233 & 42 & 2008 \\
\hline 31 & 14.1 & 0.337 & 85.473 & 28.643 & 5083 & 0.532 & 124 & 83 & 42 & 2007 \\
\hline 32 & 13.9 & 0.631 & 85.606 & 28.564 & 5325 & 0.112 & 240 & 22 & 49 & 2001 \\
\hline 33 & 13.6 & 0.576 & 88.617 & 27.976 & 4929 & 0.124 & 135 & 24 & 48 & 2001 \\
\hline 34 & 13.6 & 0.327 & 90.606 & 28.087 & 5146 & 0.128 & 759 & 54 & 42 & 2008 \\
\hline 35 & 13.1 & 0.317 & 82.207 & 29.929 & 4506 & 0.966 & 255 & 448 & 41 & 2005 \\
\hline 36 & 12.4 & 0.331 & 88.085 & 27.533 & 4821 & 0.095 & 15 & 37 & 42 & 2007 \\
\hline 37 & 12.3 & 0.302 & 89.598 & 28.187 & 4847 & 0.445 & 150 & 67 & 41 & 2002 \\
\hline 38 & 12.1 & 0.298 & 86.859 & 27.688 & 4716 & 0.612 & 255 & 197 & 41 & 2005 \\
\hline 39 & 12.1 & 0.297 & 90.648 & 28.301 & 5423 & 0.411 & 105 & 61 & 41 & 2008 \\
\hline 40 & 12.0 & 0.296 & 85.851 & 28.213 & 4334 & 0.179 & 15 & 67 & 41 & 2005 \\
\hline 41 & 11.8 & 0.336 & 86.918 & 27.833 & 5314 & 0.117 & 361 & 35 & 42 & 2005 \\
\hline 42 & 11.1 & 0.571 & 86.158 & 28.304 & 5275 & 0.122 & 109 & 19 & 48 & 2000 \\
\hline 43 & 11.1 & 0.278 & 86.644 & 27.778 & 5104 & 0.889 & 75 & 262 & 40 & 2008 \\
\hline 44 & 11.1 & 0.277 & 82.508 & 29.963 & 5036 & 0.427 & 135 & 61 & 40 & 2009 \\
\hline 45 & 10.7 & 0.316 & 90.598 & 28.05 & 4933 & 0.224 & 165 & 34 & 41 & 2008 \\
\hline 46 & 10.7 & 0.269 & 91.534 & 27.898 & 4394 & 0.941 & 45 & 181 & 40 & 2007 \\
\hline 47 & 10.6 & 0.758 & 88.067 & 27.934 & 5498 & 0.033 & 291 & 14 & 51 & 2007 \\
\hline 48 & 10.5 & 0.267 & 86.315 & 28.195 & 5215 & 0.264 & 106 & 48 & 40 & 2000 \\
\hline 49 & 10.3 & 0.262 & 88.049 & 27.545 & 4969 & 0.145 & 42 & 57 & 39 & 2007 \\
\hline
\end{tabular}




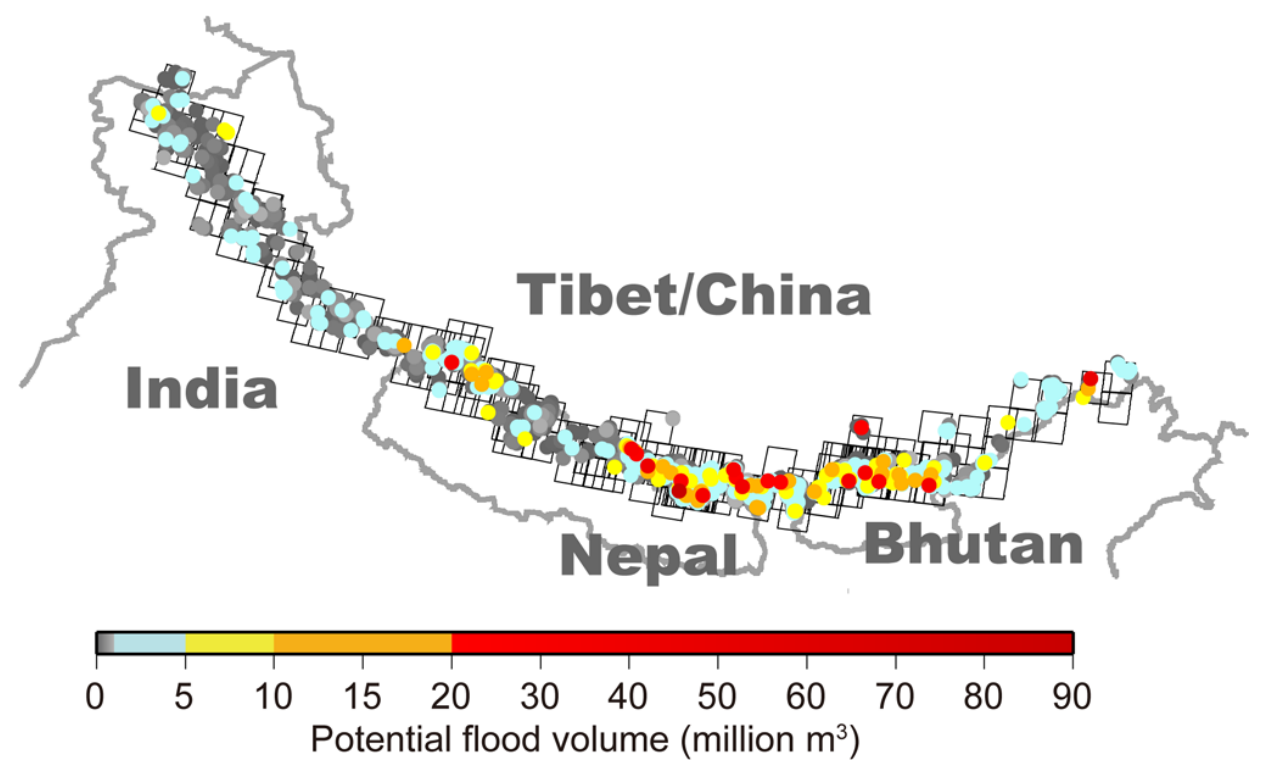

Fig. 7. Potential flood volume (PFV) of 2276 Himalayan glacial lakes. Smaller lakes are obscured by larger ones. Squares denote coverage of ASTER images used in the analysis.

Table 4. Number of Himalayan glacial lakes categorized by potential flood volume (PFV) resulted from different threshold depression angles (TDA).

\begin{tabular}{lrrrrr}
\hline $\begin{array}{l}\text { PFV } \\
\left(\text { million } \mathrm{m}^{3}\right)\end{array}$ & TDA $^{\circ}$ & TDA $^{\circ}$ & TDA $10^{\circ}$ & TDA $11^{\circ}$ & ${\text { TDA } 12^{\circ}}^{\circ}$ \\
\hline 0 & 602 & 710 & 794 & 895 & 999 \\
$<1$ & 1106 & 1043 & 1002 & 959 & 892 \\
$1-5$ & 421 & 391 & 370 & 329 & 308 \\
$5-10$ & 73 & 73 & 61 & 53 & 41 \\
$10-20$ & 45 & 37 & 31 & 25 & 21 \\
$>20$ & 29 & 22 & 18 & 15 & 15 \\
\hline Total & & & 2276 & & \\
\hline
\end{tabular}

bathymetry. On the other hand, downstream expansion of a glacial lake will result in the formation of a new SLA in front of the lake. This implies that glacial lakes with a PFV of zero may suddenly develop a very high PFV if the lake has a large surface area. In fact, Nagma Pokhari in the Nepal Himalayas showed no SLA in 1973, but downstream expansion has led to the development of an SLA and a significant PFV (32.8 million $\mathrm{m}^{3}$; Table 1) in only two years (Fig. 11). In contrast, a case study of the Imja Glacial Lake, which is the most investigated Himalayan glacial lake (e.g., Yamada, 1998; Bajracharya et al., 2007; Bolch et al., 2008; Hambrey et al., 2008; Fujita et al., 2009; Lamsal et al., 2011), showed that the lake surface has lowered gradually over the past three decades (Lamsal et al., 2011) and that the downstream shoreline has been stable since the 1990s (Fujita et al., 2009). Our analysis shows a PFV of zero for the Imja Glacial Lake, and it seems to be in a much safer state than other lakes with large PFVs. Nevertheless, slow but continuous lowering of the moraine dam (Fujita et al., 2009) may possibly result in future changes to the lakeshore downstream. Therefore, continuous monitoring of such large-scale lakes is required, even if they have a zero PFV at present.

Figure 12a and $b$ show that the PFV of many Himalayan glacial lakes is constrained by the relationship between lake area and mean depth (Fig. 2; Eq. 1). This suggests that glacial lakes with SLAs tend to have a larger potential lowering height $\left(H_{\mathrm{p}}\right)$ than their mean depth $\left(D_{\mathrm{m}}\right)$. It is reasonable to constrain the PFV using mean depth because those lakes that experienced a GLOF were not fully drained (Fig. 5). The relationship between the SLA and the PFV (Fig. 12c), and between the average depression angle of the SLA and the PFV (not shown), suggest that neither the extent of the SLA, nor its steepness, affects the PFV. The five training GLOF lakes studied here also suggest that the extent of the SLA would not correlate with the probability of their outburst due to their very small SLAs (Table 1; Figs. 5 and 12c). We also calculated a minimum distance $\left(M_{\mathrm{D}}\right)$ between the lakeshore and SLA (Fig. 1). Our five training GLOF lake sites showed an $M_{\mathrm{D}}$ of less than $200 \mathrm{~m}$. The $M_{\mathrm{D}}$ is another measure of the width of the moraine dam, and a shorter $M_{\mathrm{D}}$ implies a narrower dam and so may suggest a higher probability of outburst (Fig. 12d), although it is difficult to estimate a threshold distance.

The PFVs were simply calculated from the topography surrounding the moraine-dammed lakes and thus the robustness of the dam could not be evaluated. As the existence of ice within the damming moraine may alter the dam's vulnerability, understanding the distribution and degradation of permafrost will be an important factor for the further assessment of GLOF probability. Bolch et al. (2011) calculated the 

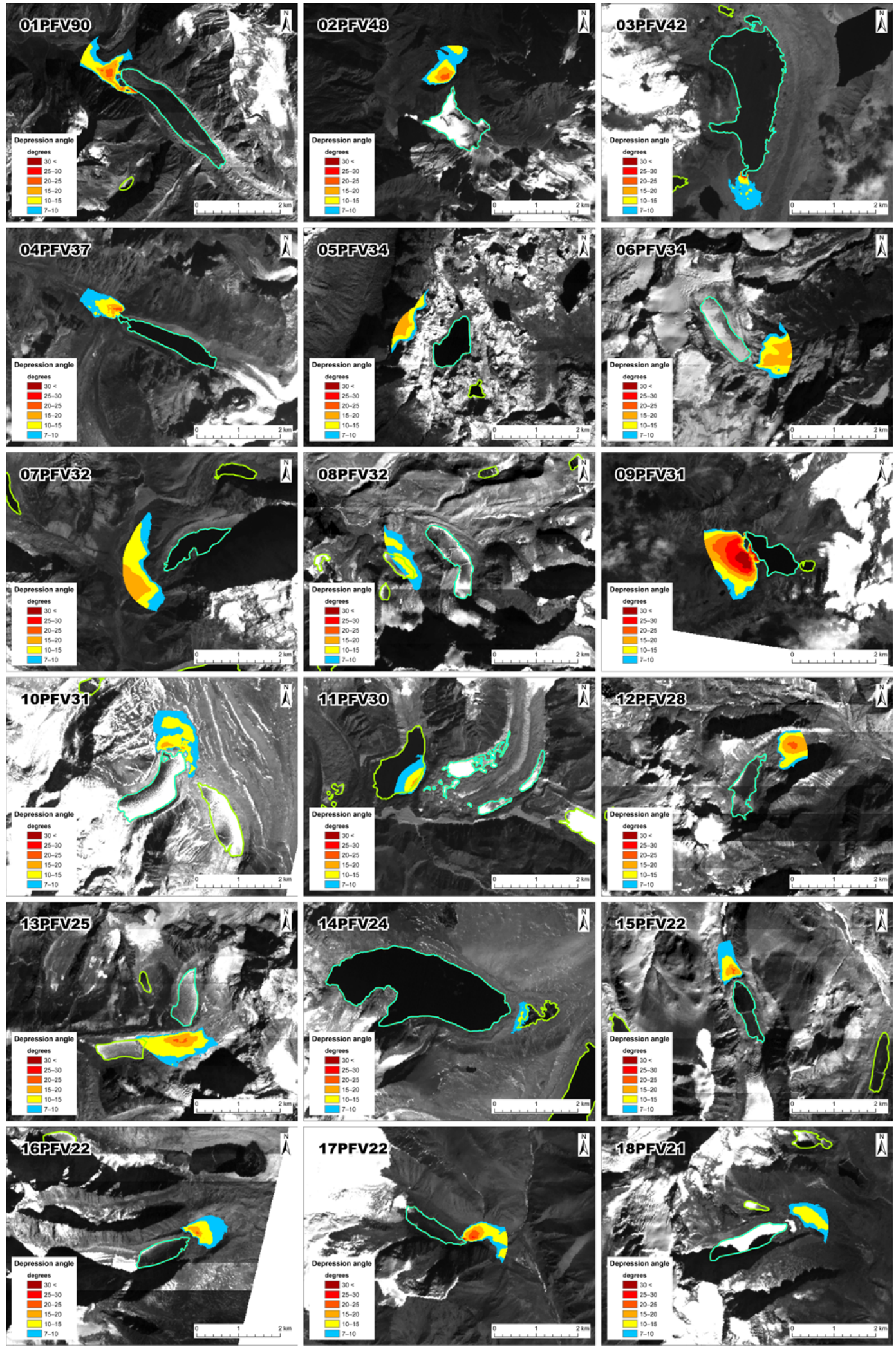

Fig. 8. Glacial lakes with a high PFV greater than 20 million $\mathrm{m}^{3}$. Light blue and light green polygons denote target and neighbouring other lakes, respectively. Steep lakefront area is shaded depending on steepness. The two digits before and after "PFV" denote its rank and volume $\left(\right.$ million $\mathrm{m}^{3}$ ), respectively (details in Table 3 ). 


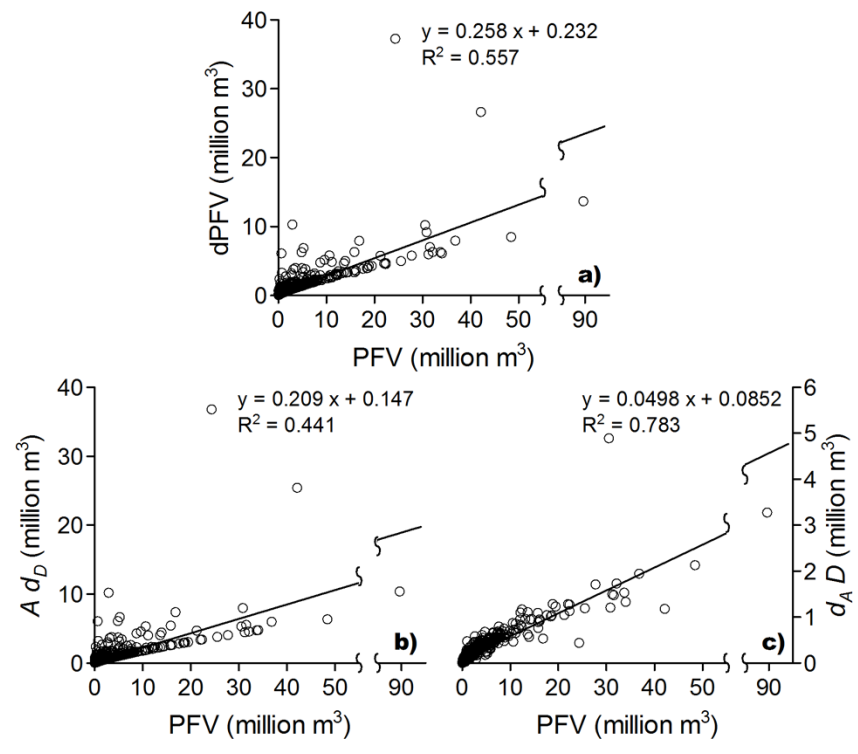

Fig. 9. Uncertainties of (a) potential flood volume (dPFV), due to (b) depth estimation $\left(A d_{D}\right)$ and (c) lake area delineation $\left(d_{A} D\right)$ against the potential flood volume (PFV). $A$ and $D$ in the vertical axes denote area and depth of lake, respectively.

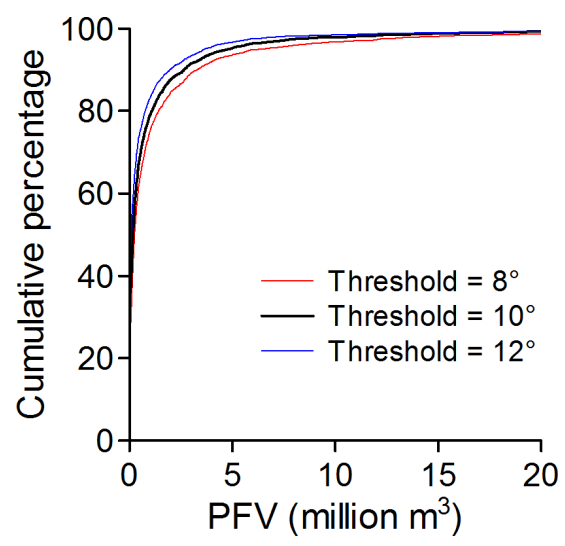

Fig. 10. Cumulative frequency distributions for the 2276 Himalayan glacial lakes against potential flood volume (PFV). PFVs in the different threshold depression angles are depicted. Lakes having PFV greater than 20 million $\mathrm{m}^{3}$ are not depicted.

distribution of permafrost for GLOF assessment in the northern Tien Shan using a permafrost model that considered geomorphometric parameters, solar radiation, and regionalized temperature conditions. In the Khumbu region of the Nepal Himalaya, Fukui et al. (2007) reported that the permafrost has degraded over the past three decades, and has melted at the elevations of the glacier termini in this region. As little information regarding permafrost is available along the Himalayas, measurements and/or modelling will be required to assist the further assessment of dam vulnerability.

Although we assumed in this study that collapse of the moraine dam was essential to release a significant volume of water, large mass slides, such as rock or ice avalanches, have often released a large amount of water by overtopping of the dams, especially in the Andes (e.g., Carey et al., 2012). Even in the Himalayas, some previous studies have focused on the outburst triggers by examining slope angles (e.g., Bolch et al., 2008; Wang et al., 2008; Wang et al., 2011). This is a limitation of our approach because the PFV does not suggest any potential triggering mechanism. On the other hand, our approach, in which we calculate the depression angle from the lake surface, may be of use for evaluating the trigger mechanisms by adopting the elevation angle from the lake towards the surrounding terrain, whereas the gradient of the surrounding slope itself and the distance between the terrain and lake have been dealt with separately in previous studies. However, it must be noted that remotely sensed DEMs are less accurate on terrain steeper than $40^{\circ}$ (Fujita et al., 2008; Nuimura et al., 2012), and on which the probability of rock/ice avalanches is high (e.g., Richardson and Reynolds, 2000). In addition, the elevation angle itself provides no information on the probability of mass movements.

The PFV defined in this study is not the sole, or even the main factor required to assess GLOF hazards, as other factors such as dam properties, the slope of the downstream river, and loose sediments must also be taken into account. On the other hand, previous assessments have often been conducted using subjective criteria because GLOF events are rare, meaning that it is difficult to determine the threshold values of the various indices from empirical evidence alone (e.g., Wang et al., 2008; Mergili and Schneider, 2011; Wang et al., 2011). Consequently, the PFV derived from previous GLOFs represents an objective and practical index to apply during the initial screening stage of the thousands of Himalayan glacial lakes. As the volume of floodwater is an important initial condition for flood simulations, the PFV will be useful for further risk assessment downstream. Despite the existence of lakes with large PFVs, however, the likely risk, and so the practical requirement to implement countermeasures, will be low if the downstream area is uninhabited and/or undeveloped. In contrast, even those glacial lakes with PFVs of less than 10 million $\mathrm{m}^{3}$ may have to be investigated in detail if they are situated at the head of a densely populated river valley. Despite its rather small flood volume of 5.0 million $\mathrm{m}^{3}$ (PFV estimated to be 7.1 million $\mathrm{m}^{3}$; Table 1), the 1985 flood from Dig Tsho in Nepal seriously damaged infrastructure, including a newly built hydropower plant, along the Bhote Kosi and Dudh Kosi rivers, which is one of the most visited trekking routes in the world (Vuichard and Zimmermann, 1987). Further flood simulation work will aid the risk assessment of those glacial lakes likely to require flood prevention measures (Bajracharya et al., 2007; Koike and Takenaka, 2012; W. Wang et al., 2012), and a high-quality DEM is essential for such simulations (W. Wang et al., 2012). 


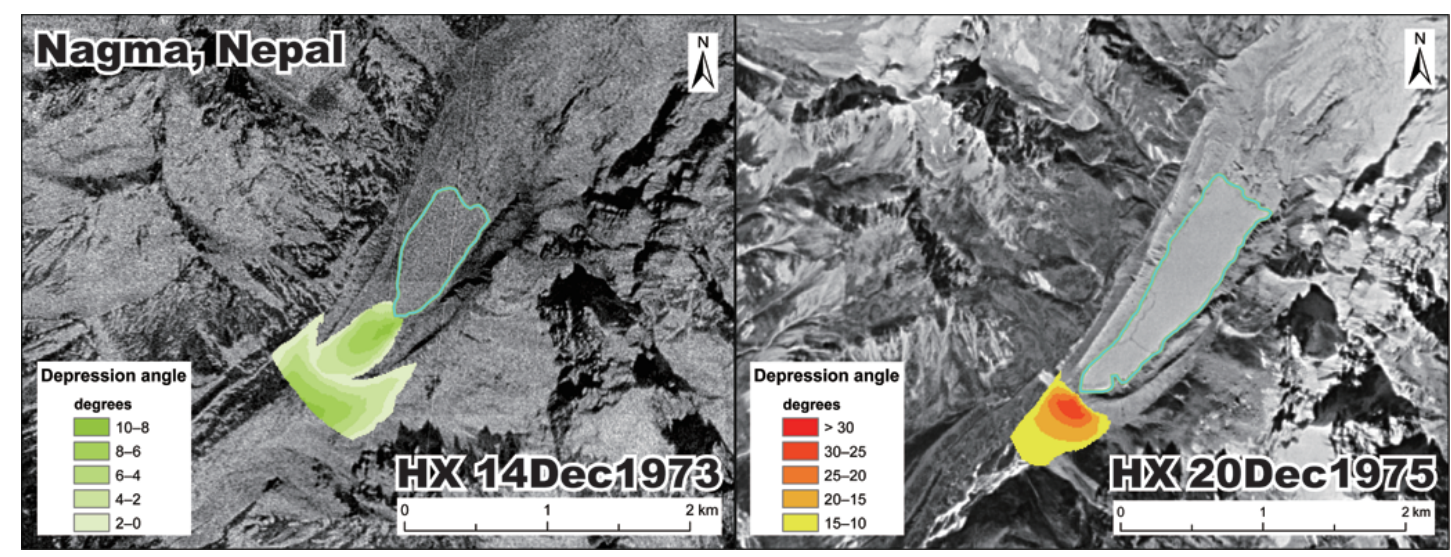

Fig. 11. Evolution of steep lakefront area associated with downstream lake expansion of the Nagma Pokhari, Nepal between December 1973 (left, PFV = 0) and December 1975 (right, PFV = 32.8 million $\mathrm{m}^{3}$ ). Both images and digital elevation models are based on Hexagon KH-9 imagery.
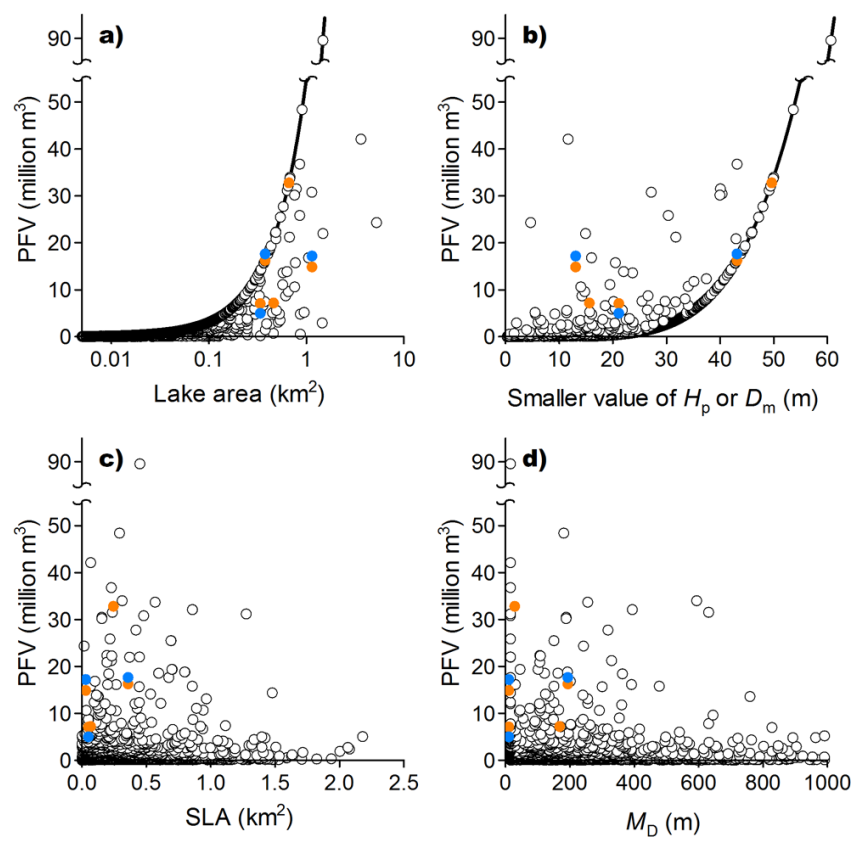

Fig. 12. Relationships of PFV with (a) lake area, (b) $H_{\mathrm{p}}$ or $D_{\mathrm{m}}$ (whichever is smaller), (c) SLA, and (d) $M_{\mathrm{D}}$ for 2276 Himalayan glacial lakes (open circles). Abbreviations are shown in Table 1. Coloured circles indicate estimates based on the method developed in this study (orange) and by other approaches (blue) for the five training GLOF lakes (Fig. 5 and Table 1). Thick lines in (a) and (b) indicate PFV values constrained by Eq. (1), which is based on the maximum approximation of the lake's mean depth (Fig. 2).

\section{Conclusions}

In order to evaluate the probability of GLOF, in situ investigation is the only way to definitively determine the lithology and structure of a moraine dam (Hambrey et al., 2008; Ohashi et al., 2012) as well as the bathymetry of the glacial lake (Yamada, 1998; Fujita et al., 2009, 2012). Nevertheless, it is impractical to conduct ground-based surveys of thousands of Himalayan glacial lakes. The concepts of SLA and PFV proposed in this study are practical indices that can be easily calculated, without any particular expertise, if remotely sensed imagery and DEMs are available. Our analysis showed that the $35 \%$ of 2276 Himalayan glacial lakes had no SLA, and consequently had a PFV of zero, though some of those lakes have been categorized as potentially dangerous glacial lakes in previous studies. The PFV distribution follows a power-law function and we identify 49 lakes with PFVs of over 10 million $\mathrm{m}^{3}$, which is a comparable volume to that of recorded major GLOFs. Lakes having smaller PFV also have to be noted if they are situated at the headwater of densely developed basins. Our PFV analysis is a preliminary but an operative approach as an initial screening of the thousands of Himalayan glacial lakes located in remote regions. The PFV list prioritizes those glacial lakes that require further detailed investigation on hazards and risk assessment, for which several other pieces of information (e.g. hydraulic and geotechnical properties of dam, topography, population and infrastructures downstream) are necessary. In addition to in situ surveys to confirm the present status of lakes with large PFVs, it is also necessary to continue monitoring the other Himalayan glacial lakes, because changes in lakeshores will not only alter existing PFVs, but may also lead to the development of new SLAs and hence PFVs.

\section{Supplementary material related to this article is available online at: \\ http://www.nat-hazards-earth-syst-sci.net/13/1827/2013/ nhess-13-1827-2013-supplement.zip.}


Acknowledgements. We thank M. Margold, H. Frey, T. Bolch and P. Tarolli for their valuable comments. This study was conducted under the Science and Technology Research Partnership for Sustainable Development (SATREPS) supported by the Japan Science and Technology Agency (JST) and the Japan International Cooperation Agency (JICA).

Edited by: P. Tarolli

Reviewed by: M. Margold, H. Frey, and T. Bolch

\section{References}

Bajracharya, B., Shrestha, A. B., and Rajbhandari, L.: Glacial lake outburst floods in the Sagarmatha region: hazard assessment using GIS and hydrodynamic modeling, Mt. Res. Dev., 27, 336344, doi:10.1659/mrd.0783, 2007.

Benn, D. I., Wiseman, S., and Warren, C. R.: Rapid growth of a supraglacial lake, Ngozumpa Glacier, Khumbu Himal, Nepal, Int. Assoc. Hydrol. Sci., 264, 177-185, 2000.

Bolch, T., Buchroithner, M. F., Peters, J., Baessler, M., and Bajracharya, S.: Identification of glacier motion and potentially dangerous glacial lakes in the Mt. Everest region/Nepal using spaceborne imagery, Nat. Hazards Earth Syst. Sci., 8, 13291340, doi:10.5194/nhess-8-1329-2008, 2008.

Bolch, T., Peters, J., Yegorov, A., Pradhan, B., Buchroithner, M., and Blagoveshchensky, V.: Identification of potentially dangerous glacial lakes in the northern Tien Shan, Nat. Hazards, 59, 1691-1714, doi:10.1007/s11069-011-9860-2, 2011.

Carey, M., Huggel, C., Bury, J., Portocarrero, C., and Haeberli, W.: An integrated socio-environmental framework for glacier hazard management and climate change adaptation: lessons from Lake 513, Cordillera Blanca, Peru, Climatic Change, 12, 733767, doi:10.1007/s10584-011-0249-8, 2012.

Clague, J. J. and Evans, S. G.: A review of catastrophic drainage of moraine-dammed lakes in British Columbia, Quaternary Sci. Rev., 19, 1763-1783, doi:10.1016/S0277-3791(00)00090-1, 2000.

Costa, J. E. and Schuster, R. L.: The formation and failure of natural dams, Geol. Soc. Am. Bull., 100, 1054-1068, doi:10.1130/00167606(1988) $100<1054$ :TFAFON>2.3.CO;2, 1988.

Dwivedi, S. R., Acharya, M. D., and Simard, R.: The Tam Pokhari Glacier Lake outburst flood of 3 September 1998, J. Nepal Geol. Soc., 22, 539-546, 2000.

Fujisada, H., Bailey, G. B., Kelly, G. G., Hara, S., and Abrams, M. J.: ASTER DEM performance, IEEE T. Geosci. Remote Sens., 43, 2702-2714, doi:10.1109/TGRS.2005.847924, 2005.

Fujita, K., Suzuki, R., Nuimura, T., and Sakai, A.: Performance of ASTER and SRTM DEMs, and their potential for assessing glacial lakes in the Lunana region, Bhutan Himalaya, J. Glaciol., 54, 220-228, doi:10.3189/002214308784886162, 2008.

Fujita, K., Sakai, A., Nuimura, T., Yamaguchi, S., and Sharma, R. R.: Recent changes in Imja Glacial Lake and its damming moraine in the Nepal Himalaya revealed by in situ surveys and multi-temporal ASTER imagery, Environ. Res. Lett., 4, 045205, doi:10.1088/1748-9326/4/4/045205, 2009.

Fujita, K., Nishimura, K., Komori, J., Iwata, S., Ukita, J., Tadono, T., and Koike, T.: Outline of research project on glacial lake outburst floods in the Bhutan Himalayas, Global Environ. Res., 16, 3-12, 2012.
Fukui, K., Fujii, Y., Ageta, Y., and Asahi, K.: Changes in the lower limit of mountain permafrost between 1973 and 2004 in the Khumbu Himal, the Nepal Himalayas, Global Planet. Change, 55, 251-256, doi:10.1016/j.gloplacha.2006.06.002, 2007.

Gardelle, J., Arnaud, Y., and Berthier, E.: Contrasted evolution of glacial lakes along the Hindu Kush Himalaya mountain range between 1990 and 2009, Global Planet. Change, 75, 47-55, doi:10.1016/j.gloplacha.2010.10.003, 2011.

Hambrey, M. J., Quincey, D. J., Glasser, N. F., Reynolds, J. M., Richardson, S. J., and Clemmens, S.: Sedimentological, geomorphological and dynamic context of debris-mantled glaciers, Mount Everest (Sagarmatha) region, Nepal, Quaternary Sci. Rev., 27, 2361-2389, doi:10.1016/j.quascirev.2008.08.010, 2008.

Huggel, C., Kääb, A., Haeberli, W., Teysseire, P., and Paul, F.: Remote sensing based assessment of hazards from glacier lake outbursts: a case study in the Swiss Alps, Can. Geotech. J., 39, 316330, doi:10.1139/T01-099, 2002.

International Centre for Integrated Mountain Development: Glacial lakes and glacial lake outburst floods in Nepal, ICIMOD, Kathmandu, Nepal, 99 pp., 2011.

Iwata, S., Ageta, Y., Naito, N., Sakai, A., Narama, C., and Karma: Glacial lakes and their outburst flood assessment in the Bhutan Himalaya, Global Environ. Res., 6, 3-17, 2002.

Koike, T. and Takenaka, S.: Scenario analysis on risks of glacial lake outburst floods on the Mangde Chhu River, Bhutan, Global Environ. Res., 16, 41-49, 2012.

Komori, J., Koike, T., Yamanokuchi, T., and Tshering, P.: Glacial lake outburst events in the Bhutan Himalayas, Global Environ. Res., 16, 59-70, 2012.

Lamsal, D., Sawagaki, T., and Watanabe, T.: Digital terrain modelling using Corona and ALOS PRISM data to investigate the distal part of Imja Glacier, Khumbu Himal, Nepal, J. Mt. Sci., 8, 390-402, doi:10.1007/s11629-011-2064-0, 2011.

Liu, C. and Sharma, C. K.: Report on first expedition to glaciers and glacier lakes in the Pumqu (Arun) and Poiqu (Bhote-SunKosi) River Basin, Xizang (Tibet), China, Science Press, Beijing, China, 192 pp., 1988.

McKillop, R. J. and Clague, J. J.: A procedure for making objective preliminary assessments of outburst flood hazard from moraine dammed lakes in southwestern British Columbia, Nat. Hazards, 41, 131-157, doi:10.1007/s11069-006-9028-7, 2007a.

McKillop, R. J. and Clague, J. J.: Statistical, remote sensingbased approach for estimating the probability of catastrophic drainage from moraine-dammed lakes in southwestern British Columbia, Global Planet. Change, 56, 153-171, doi:10.1016/j.gloplacha.2006.07.004, 2007b.

Mergili, M. and Schneider, J. F.: Regional-scale analysis of lake outburst hazards in the southwestern Pamir, Tajikistan, based on remote sensing and GIS, Nat. Hazards Earth Syst. Sci., 11, 14471462, doi:10.5194/nhess-11-1447-2011, 2011.

Mool, P. K., Bajracharya, S. R., and Joshi, S. P.: Inventory of glaciers, glacial lakes and glacial lake outburst floods, Nepal, ICIMOD, Kathmandu, Nepal, 363 pp., 2001a.

Mool, P. K., Wangda, D., Bajracharya, S. R., Kunzang, K., Gurung, D. R., and Joshi, S. P.: Inventory of glaciers, glacial lakes and glacial lake outburst floods, Bhutan, ICIMOD, Kathmandu, Nepal, 227 pp., $2001 b$. 
Nuimura, T., Fujita, K., Yamaguchi, S., and Sharma, R. R.: Elevation changes of glaciers revealed by multitemporal digital elevation models calibrated by GPS survey in the Khumbu region, Nepal Himalaya, 1992-2008, J. Glaciol., 58, 648-656, doi:10.3189/2012JoG11J061, 2012.

Ohashi, K., Koike, T., Takenaka, S., and Umemura, J.: Study on applicability of electric sounding for interpretation of the internal structure of glacial moraines, Global Environ. Res., 16, 51-58, 2012.

Reynolds, J. M.: Glacial hazard assessment at Tsho Rolpa, Rolwaling, central Nepal, Q. J. Eng. Geol. Hydroge., 32, 209-214, 1999.

Richardson, S. D. and Reynolds, J. M.: An overview of glacial hazards in the Himalayas, Quaternary Int., 65/66, 31-47, doi:10.1016/S1040-6182(99)00035-X, 2000.

Sakai, A.: Glacial lakes in the Himalayas: a review on formation and expansion processes, Global Environ. Res., 16, 23-30, 2012.

Sawagaki, T., Lamsal, D., Byers, A. C., and Watanabe, T.: Changes in surface morphology and glacial lake development of Chamlang South Glacier in the eastern Nepal Himalaya since 1964, Global Environ. Res., 16, 83-94, 2012.

Surazakov, A. B. and Aizen, V. B.: Positional accuracy evaluation of declassified Hexagon KH-9 mapping camera imagery, Photogramm. Eng. Rem. S., 76, 603-608, 2010.

Vuichard, D. and Zimmerman, M.: The 1985 catastrophic drainage of a moraine-dammed lake, Khumbu Himal, Nepal: cause and consequences, Mt. Res. Dev., 7, 91-110, doi:10.2307/3673305, 1987.
Wang, W., Yao, T., Gao, Y., Yang, X., and Kattel, D. B.: A firstorder method to identify potentially dangerous glacial lakes in a region of the southeastern Tibetan Plateau, Mt. Res. Dev., 31, 122-130, 2011.

Wang, W., Yang, X., and Yao, T.: Evaluation of ASTER GDEM and SRTM and their suitability in hydraulic modelling of a glacial lake outburst flood in southeast Tibet, Hydrol. Process., 26, 213 225, doi:10.1002/hyp.8127, 2012.

Wang, X., Liu, S., Guo, W., and Xu, J.: Assessment and simulation of glacier lake outburst floods for Longbasaba and Pida lakes, China, Mt. Res. Dev., 28, 310-317, doi:10.1659/mrd.0894, 2008.

Wang, X., Liu, S., Ding, Y., Guo, W., Jiang, Z., Lin, J., and Han, Y.: An approach for estimating the breach probabilities of moraine-dammed lakes in the Chinese Himalayas using remotesensing data, Nat. Hazards Earth Syst. Sci., 12, 3109-3122, doi:10.5194/nhess-12-3109-2012, 2012.

Yamada, T.: Glacier lake and its outburst flood in the Nepal Himalaya, Monograph No. 1, Data Center for Glacier Research, Japanese Society of Snow and Ice, Tokyo, 96 pp., 1998.

Yamada, T., Naito, N., Kohshima, S., Fushimi, H., Nakazawa, F., Segawa, T., Uetake, J., Suzuki, R., Sato, N., Karma, Chhetri, I. K., Gyenden, L., Yabuki, H., and Chikita, K.: Outline of 2002 research activities on glaciers and glacier lakes in Lunana region, Bhutan Himalayas, Bull. Glaciol. Res., 21, 79-90, 2004. 